\title{
Smart government: analysis of dimensions from the perspective of public managers
}

\section{Claudia Melati 1}

\section{Raquel Janissek-Muniz}

1 Universidade Federal do Rio Grande do Sul / School of Administration, Graduate Program in Administration, Porto Alegre / RS - Brazil

Recent studies show that the concept of smart government and its respective dimensions are not yet consolidated. The issue of the efficiency of public activity suggests that smart government should be recognized and better explored in public management. This study brings an original contribution to the literature, presenting an analysis of the recognition, importance, and application of the concept's dimensions from the perspective of public managers. Adopting a qualitative and exploratory approach, operationalized through interviews with public managers in the South of Brazil, we sought to identify the dimensions of smart government that are recognized and applied by public managers. The results show the concept's importance and its application and benefits in public administration. The findings point out the most influencital dimensions and their importance in the process, with emphasis on the organizational culture and the organization of data and public information.

Keywords: government intelligence; smart government; public management.

\section{Governo inteligente: análise de dimensões sob a perspectiva de gestores públicos}

Estudos recentes apontam que o conceito de governo inteligente e suas respectivas dimensões ainda não estão consolidados. Considerando a importância do tema para a eficiência da atividade pública, seu entendimento e seu reconhecimento para a gestão pública são questões que devem ser mais bem exploradas. Com tal intuito, este estudo traz uma contribuição original ainda não abordada na literatura, apresentando uma análise do reconhecimento, da importância e da aplicação das referidas dimensões sob a perspectiva de gestores públicos. A partir de uma abordagem qualitativa e exploratória, operacionalizada por meio de entrevistas com gestores públicos do Sul do Brasil, buscou-se identificar dimensões de governo inteligente reconhecidas e aplicadas na gestão pública. Os resultados reconhecem a importância do conceito e sua aplicação e benefícios na administração pública e apontam as dimensões com maior influência e importância no processo, com destaque para a cultura organizacional e a organização de dados e informações públicas.

Palavras-chave: inteligência em governo; smart government; gestão pública.

\section{Inteligencia gubernamental: análisis de dimensiones desde la perspectiva de gestores públicos}

Estudios recientes muestran que el concepto de gobierno inteligente y sus respectivas dimensiones aún no están consolidados. Teniendo en cuenta la importancia del tema para la eficiencia de la actividad pública, su comprensión y reconocimiento para la gestión pública son cuestiones que deberían explorarse mejor. Con ese fin, este estudio aporta una contribución original aún no abordada en la literatura, presentando un análisis del reconocimiento, importancia y aplicación de dichas dimensiones desde la perspectiva de los gestores públicos. Desde un enfoque cualitativo y exploratorio, operacionalizado a través de entrevistas con gestores públicos del sur de Brasil, se buscó identificar dimensiones de gobierno inteligente reconocidas y aplicadas en la gestión pública. Los resultados reconocen la importancia del concepto y su aplicación y los beneficios en la administración pública y señalan las dimensiones con mayor influencia e importancia en el proceso, con énfasis en la cultura organizacional y la organización de datos e información pública.

Palabras clave: inteligencia gubernamental; smart government; gestión pública. 


\section{INTRODUCTION}

The Brazilian federal government started a process of modernizing public administration at the beginning of the 1990s, focusing on management efficiency based on cost reduction and result-oriented activities, as well as adopting more managerial and less bureaucratic assumptions (Abrucio, 2007; Batista, 2012; Bresser-Pereira, 1996; De Paula, 2005; Klering, Porsse, \& Guadagnin, 2010). By the mid-2000s, e-government emerged to transform the government's relationship with society, offering interactivity with citizens, companies, and government agencies. E-government has contributed to the delivery of public services in a dynamic way, promoting a more efficient administration, concerned with the citizens' quality of life, and with the quality of management (Guimarães \& Medeiros, 2005; Rezende, 2018).

For Ribeiro, Pereira, and Benedicto (2013), public administration reforms contributed to improving political decision-making capabilities and to state's decentralization, implementing horizontal coordination, and updating the personnel's managerial capacity. The trend observed in the past decade showed the construction of a more participatory, efficient, and integrated public administration (Capobiango, Nascimento, Silva, \& Faroni, 2013; De Paula, 2005; Secchi, 2009), providing better management in the provision of public services. Gil-Garcia, Helbig, and Ojo (2014) demonstrate that different levels and branches of governments are adopting tools and applications to organize the administration and operate in a rapidly changing environment, seeking to respond to society's demands for quality and effective services (Schaefer, Macadar, \& Luciano, 2017).

Johnston and Hansen (2011) advocate the need for smart government infrastructure to the individuals' collective capacities to organize, interact, and govern, overcoming complex social challenges. For the authors, such infrastructure is more agile and efficient than the ones set under the paradigms guiding the current government. Other studies point out key factors to establish smart governments able to cope with complexity and uncertainty, such as coordination, continued engagement, and access to open data and shared information (Gil-Garcia et al., 2014; H. J. Scholl \& M. C. Scholl, 2014).

Studies on government intelligence (Cepik, 1997; Desouza, 2005; Gil-Garcia, Pardo, \& AldamaNalda, 2013; Jiménez, Solanas, \& Falcone, 2014; Johnston \& Hansen, 2011; Linders, Liao, \& Wang, 2015; Viorel \& Radu, 2015) show that the public sector has specificities in comparison to the private sector regarding intelligence activity, and emphasize the importance of the government's continuous environmental monitoring and analysis of data.

The research on intelligence and government shows that the terms 'smart government' or 'government intelligence' do not entirely relate to the concept of intelligence used to refer to monitoring activities conducted to collect data that produce the information and knowledge to subsidize decisionmaking. The terms incorporate the notion of the service delivered from data and information from the context (Andriotti, Freitas, \& Janissek-Muniz, 2008; Janissek-Muniz, Lesca, \& Freitas, 2006). However, there is no consensus regarding the concept and definition of smart government, which suggests the need for further studies. Recent studies point to elements collaborating to the development of a unified concept of smart and open government (Gil-Garcia et al., 2014; Gil-Garcia, Zhang, \& Puron-Cid, 2016; H. J. Scholl \& M. C. Scholl, 2014). 
In addition to unifying concepts, government professionals must understand how a more efficient, effective, transparent, and collaborative management and provision of public services leads to a smarter government, as well as using such understanding to develop strategies able to improve the use of intelligence in government (Nam \& Pardo, 2011).

Although there is no consensus on the limits of the term, this study considers, in a concise way, that "smart government" is a government capable of feeling and reacting to the environment, through collecting data to be transformed into information and knowledge to improve decision-making in the public sector. The research aimed to identify the dimensions of smart government that are recognized and adopted by public managers, contributing to the consolidation of the concept. In addition, the analysis of the relevance and applicability of the dimensions of intelligence (smartness) can assist the most diverse governmental spheres in the development of policies related to the qualification of evidence-based decision-making.

Including this introduction, the article is organized in 5 sections. The second section below presents the concept of intelligence in the context of public management and its evolution towards the smart government. The third describes the method adopted, followed by a section showing the results obtained. The fifth section presents the final considerations.

\section{GOVERNMENT INTELLIGENCE}

According to Herman (1996, p. 1),

[...] Governments collect process and use information. [...] But 'intelligence' in government usually has a more restricted meaning than just information and information services. It has particular associations with international relations, defence, national security and secrecy, and with specialized institutions labelled 'intelligence'.

For Herman (1996), several studies on intelligence and government emphasize national security (Cepik, 2005; Desouza, 2005; Paula \& Rover, 2012; Veronese, 2013), particularly analyzing the role of intelligence agencies in each country. According to Paula and Rover (2012, p. 220, our translation),

The importance of activities of intelligence is also based on the need for societies' protection and development. The implementation of national intelligence systems and the flow of information have been a practice in warfare, diplomacy, maintenance of internal order, and, more recently, the control of internal order and the need for public security activities.

Desouza (2005) points out that data are traditionally collected from two or more sources (such as satellite images; voice and data transmission; human informants) and are synthesized and evaluated to become information, used afterward in decision-making. The information is used based on the particular issues of each context, resulting in actions and services to the public.

Several studies on the importance of information as a driver of managerial decision making (Andriotti et al., 2008; Choo, 2002; Davenport, 1998; Janissek-Muniz et al., 2006; Paula \& Rover, 
2012) show the need to monitor the organization's external environment, in order to understand it based on the selective interpretation of information. This process is considered the organizations' intelligence activity.

Another issue often present in the literature on intelligence in the public sector is the use of information and communication technologies (ICT) in government (Gil-Garcia et al., 2013; GilGarcia et al., 2016; H. J. Scholl \& M. C. Scholl, 2014; Johnston \& Hansen, 2011; Paula \& Rover, 2012). Governments use ICT for different purposes, such as collecting data to support decision-making processes and improve services (Gil-Garcia et al., 2013). In addition, with the use of ICT, adequate data and strategies may contribute to reduce social exclusion and promote social justice (Gil-Garcia et al., 2016). The research by Linders et al. (2015) shows that studies are exploring the potential of ICT to drive transformative change in government and governance.

For H. J. Scholl and M.C. Scholl (2014, p. 163),

[...] actionable and omnipresent information along with its underlying technologies are substantial prerequisites and backbones for developing models of smart (democratic) governance, which foster smart, open, and agile governmental institutions as well as stakeholder participation and collaboration on all levels and in all branches of the governing process.

In the study by Liu and Zheng (2015), the authors connect smart government to the provision of public service, efficiency and effectiveness of the services, and address governmental and societal issues through cross-departmental collaboration.

Smart government may be observed through multiple dimensions of intelligence, each of them contributing individually or in an integrated way to the development of smart government (GilGarcia et al., 2016). For the authors, 'intelligence' ('smartness') should be conceptualized in a broad and multifaceted way.

Another issue to be highlighted regarding smart government is evidence-based decision making since data-driven decisions and the increasing use of data collected through omnipresent sensory devices, advanced assessment, and integrated applications, help to improve government's decisionmaking (Gil-Garcia et al., 2016).

Therefore, it is possible to observe an original link of the intelligence process with the areas of security and foreign affairs (Cepik, 1997, 2005; Herman, 1996). Over the years, however, studies have expanded the scope of the concept of government intelligence, using information from the context to address issues such as efficiency in public activities and the delivery of quality public services, as well as the increasing participation of civil society in the public sphere (Gil-Garcia et al., 2013; Gil-Garcia et al., 2014; H. J. Scholl \& M. C. Scholl, 2014; Johnston \& Hansen, 2011).

From this evolutionary perspective, more recent studies (Eom, Choi, \& Sung, 2016; Gil-Garcia et al., 2014; Gil-Garcia et al., 2016; H. J. Scholl \& M. C. Scholl, 2014; Johnston \& Hansen, 2011) have put forward the notion of smart government as a new concept to be explored in-depth.

The meaning and explanation of the idea of smart government listed in Box 1 indicate the relevance of the concept for the development of public activities. 


\begin{tabular}{|c|c|c|}
\hline Author & Year & Smart Government \\
\hline Johnston and Hansen & 2011 & $\begin{array}{l}\text { Smart governance infrastructures increase society's ability to organize, interact, } \\
\text { and govern to overcome complex social challenges. They make the government } \\
\text { more responsive and efficient than the traditional governance infrastructures. }\end{array}$ \\
\hline Gil-Garcia et al. & 2014 & $\begin{array}{l}\text { "Smart government is used to characterize activities that creatively invest in } \\
\text { emergent technologies coupled with innovative strategies to achieve more agile } \\
\text { and resilient government structures and governance infrastructures" ( } p \text {. 11). }\end{array}$ \\
\hline H. J. Scholl and M. C. Scholl & 2014 & $\begin{array}{l}\text { Smart governmental institutions adopt practices of open and agile government } \\
\text { and incentive "stakeholder participation and collaboration on all levels and in all } \\
\text { branches of the governing process" (p.163). }\end{array}$ \\
\hline Liu and Zheng & 2015 & $\begin{array}{l}\text { Smart government may be related to the quality of service delivery to citizens, to } \\
\text { efficiency and efficacy of such services, and to addressing wicked problems by } \\
\text { adopting cross-departmental collaboration. }\end{array}$ \\
\hline Eom et al. & 2016 & $\begin{array}{l}\text { 'Smart' emerges as a keyword in government reform strategies. Although there } \\
\text { are many different perspectives on smart government, it can be broadly considered } \\
\text { as the adoption of "a creative mix of emerging technologies and innovation in the } \\
\text { public sector" (Eom et al., 2016). }\end{array}$ \\
\hline
\end{tabular}

Source: Elaborated by the authors.

The concept of smart government is primarily related to agility and efficiency in government due to the use of ICT and the participation and collaboration of citizens, companies, and other stakeholders such as nonprofits.

Studies have shown a convergence to the concept of intelligence (or smartness) linked to the activity of monitoring the environment to obtain data and transform it into information and knowledge to support decision-making (Gil-Garcia et al., 2013; Gil-Garcia et al., 2016; H. J. Scholl \& M. C. Scholl, 2014) since smart governments are able to feel and react to the environment based on data relevant to their decision making (Gil-Garcia et al., 2016).

For Gil-Garcia, Zhang, and Puron-Cid (2016), the capacity for data management and information processing and sharing through ICT are considered critical factors for partnerships and interorganizational communications among stakeholders of smart government initiatives. H. J. Scholl and M. C. Scholl (2014, p. 166) also outlined elements characteristics of smart governments "such as openness and transparency of government decision-making and actions, open information sharing, stakeholder participation and collaboration, leveraging government operations and services via intelligent and integrated technology use, as well as government's role of facilitator of innovation, sustainability, competitiveness, and livability."

Other key points in the literature on smart government:

- According to Johnston and Hansen (2011, p. 9) "Smart governance infrastructures are needed to effectively harness the unique skills and knowledge that too often lie dormant in the crowd;" 
- The government's context of operation is complex and offers a lot of data and information on several areas such as security, health, education (Cepik, 2005; Desouza, 2005);

- For Paula and Rover (2012, p. 225, our translation) ICTs "are devices and tools that assist in the process of managing, organizing, treating, and disseminating information, as well as contributing to building knowledge for organizations." For Gil-Garcia et al. (2013), such tools enhance the government's decision-making and service delivery.

The literature review on smart government made it possible to identify significant dimensions, as shown in Box 2.

\section{BOX 2 DIMENSIONS OF SMART GOVERNMENT}

\begin{tabular}{|c|c|c|}
\hline Dimension & Meaning & Authors \\
\hline $\begin{array}{l}\text { Use of external data } \\
\text { and information }\end{array}$ & $\begin{array}{l}\text { Highlights the importance of the use of data and } \\
\text { information latent in the population, and that may } \\
\text { contribute to public management. }\end{array}$ & $\begin{array}{l}\text { Gil-Garcia et al. (2013); Gil-Garcia et al. } \\
\text { (2016); H. J. Scholl and M. C. Scholl (2014) }\end{array}$ \\
\hline $\begin{array}{l}\text { Organizational culture } \\
\text { based on intelligence }\end{array}$ & $\begin{array}{l}\text { Encourages a culture of awareness and information } \\
\text { sharing through networks; data collection and } \\
\text { external information; effective use of information to } \\
\text { develop the work and support the public manager's } \\
\text { decision-making. }\end{array}$ & $\begin{array}{l}\text { Lesca and Janissek-Muniz (2015); } \\
\text { Schoemaker and Day (2009); Xu (2007) }\end{array}$ \\
\hline $\begin{array}{l}\text { Management } \\
\text { efficiency and } \\
\text { effectiveness }\end{array}$ & $\begin{array}{l}\text { Efficiency and effectiveness of public management, } \\
\text { proper use of ICT, data, and information, and society's } \\
\text { participation. }\end{array}$ & $\begin{array}{l}\text { H. J. Scholl and M. C. Scholl (2014); Liu and } \\
\text { Zheng (2015) }\end{array}$ \\
\hline $\begin{array}{l}\text { Effective use of } \\
\text { technologies (big data, } \\
\text { business intelligence) }\end{array}$ & $\begin{array}{l}\text { The use of ICTs for different purposes within the } \\
\text { government, such as collection, processing, and } \\
\text { sharing of data and information that will support } \\
\text { decision-making and improve the delivery of public } \\
\text { services. }\end{array}$ & $\begin{array}{l}\text { Gil-Garcia et al. (2013); Gil-Garcia et al. } \\
\text { (2016); H. J. Scholl and M. C. Scholl (2014); } \\
\text { Johnston and Hansen (2011); Linders et } \\
\text { al. (2015); Paula and Rover (2012); Wang, } \\
\text { Zhang, Li, and Ruan (2016) }\end{array}$ \\
\hline $\begin{array}{l}\text { Evidence-based } \\
\text { decision-making }\end{array}$ & $\begin{array}{l}\text { Increasing data-driven decision making through } \\
\text { omnipresent use of sensory devices, advanced } \\
\text { assessment, and integrated applications allow } \\
\text { governments to make informed decisions. }\end{array}$ & $\begin{array}{l}\text { Gil-Garcia et al. (2016); H. J. Scholl and M. C. } \\
\text { Scholl (2014) }\end{array}$ \\
\hline Social engagement & $\begin{array}{l}\text { Society's active participation in the development of } \\
\text { public management. }\end{array}$ & $\begin{array}{l}\text { Eom et al. (2016); Gil-Garcia et al. (2014); } \\
\text { Gil-Garcia et al. (2013); H. J. Scholl and M. C. } \\
\text { Scholl (2014); Johnston and Hansen (2011) }\end{array}$ \\
\hline $\begin{array}{l}\text { Cross-departmental } \\
\text { and inter- } \\
\text { organizational } \\
\text { collaboration }\end{array}$ & $\begin{array}{l}\text { Sharing data and information among several agencies } \\
\text { of the public sector, through collaboration and } \\
\text { development of unified public activities to improve } \\
\text { services. }\end{array}$ & Gil-Garcia et al. (2016); Liu and Zheng (2015) \\
\hline
\end{tabular}




\begin{tabular}{lll} 
Dimension & \multicolumn{1}{c}{ Meaning } & \multicolumn{1}{c}{ Authors } \\
$\begin{array}{l}\text { Agile government } \\
\text { Improving the delivery of public service through } \\
\text { the massive use of ICT, data and information, and } \\
\text { society's participation }\end{array}$ & $\begin{array}{l}\text { H. J. Scholl and M. C. Scholl (2014); Johnston } \\
\text { and Hansen (2011) }\end{array}$ \\
$\begin{array}{l}\text { Innovation, co- } \\
\text { creation, collective } \\
\text { intelligence }\end{array}$ & $\begin{array}{l}\text { Refining processes; insights on new public policies; } \\
\text { new forms of communication between government } \\
\text { and society; sharing decision-making by using } \\
\text { collective intelligence. }\end{array}$ & $\begin{array}{l}\text { Oberli (2018); Juniawan, Sandhyaduhita, } \\
\text { Purwandari, Yudhoatmojo, and Dewi (2017); } \\
\text { Nam (2016) }\end{array}$
\end{tabular}

Source: Elaborated by the authors.

\section{METHODOLOGY}

In order to identify the dimensions of smart government that managers recognize and apply in their activity, the study adopted a qualitative and exploratory approach, considering that "one of the key benefits of qualitative research is that it allows a researcher to see and understand the context within which decisions and actions take place" (Myers, 2013, p. 5). According to the author, qualitative researchers argue that qualitative research is the appropriate choice if one wants to understand, indepth, people's motivations, reasons, actions, beliefs, and their context. The research is an exploratory study because it addresses a relatively new topic, where there is still not much work developed, especially in Brazil.

The study used the Web of Science, SciELO, and SCOPUS databases, as well as the most prominent journals recommended by the Association of Information Systems (AIS). The terms used as search criteria were: "government or public administration" AND "intelligence or forecast or corporate foresight or weak signal or environmental scanning or future studies or strategic foresight or scenario planning or smart." The search resulted in 164 articles, analyzed to identify dimensions of smart government and elements that support it, offering subsidies to elaborate questions for interviews with public managers.

According to Triviños (1987), semi-structured interviews are characterized by basic questions that are supported by theories related to the subject studied. For the author, semistructured interviews favor the description of social phenomena and their explanation and broad understanding, as well as recognizing the researcher's conscious and active presence in the process of collecting information.

Using the interview questions presented in Box 3, the study conducted ten interviews with public managers working in two secretariats of one of the southern states of Brazil. The state secretariats chosen have a cross-cutting characteristic, which means that they are linked to the other state agencies. The interviews were conducted in May and June 2018 and lasted an average of 30 minutes. 


\section{BOX $3 \quad$ INTERVIEW QUESTIONS}

Name:

Sex:

Age:

Job position:

Length of time in civil service:

1. Based on the concept of smart government exposed, how do you think the process of government intelligence is established?

2. Can you list some of the benefits of this process both from the perspective of internal management and the delivery of public services?

3. Studies highlight specific dimensions regarding government intelligence. Can you comment on these dimensions?

- External data and information for decision-making

- Organizational Culture

- Management efficiency and effectiveness

- Use of big data and business intelligence systems

- Technology for developing intelligence processes

- Evidence-based decisions

- Social engagement in building efficient management

- Cross-departmental and interorganizational collaboration

- Government agility

- How do you understand the current situation in the government concerning issues such as innovation, interoperation, creation, collective intelligence?

4. Do you think the government is effectively using the large amount of data and information that is latent in the environment?

5. What institutional and structural dimensions do you consider essential for the further development of intelligence activity in government?

6. What behavioral dimensions (organizational and individual), would you highlight?

7. Have you noticed considerable changes in relation to the subject (smart government/government intelligence) in public administration? Since when?

8. Is there anything you would like to add or expand on?

Final thanks.

Source: Elaborated by the authors.

The interviewees were chosen based on ease of access and were recruited by the previous interviewee. The recruited participant was selected to be interviewed as long as they met the requirement of being a manager in a state agency or department. As for the profile of the ten interviewees, seven were men, four had been working for more than 20 years in civil service, and five were in executive positions in the state agencies. The interviewees worked in different sectors, such as public procurement, fundraising, government planning, and information systems.

The interviewees are not categorized according to their specific area of work since the public administration has numerous areas of activity, from running the routine state apparatus, to the activities 
of service provision, in direct contact with citizens. Interviewees were contacted via email or telephone to check their availability. They were informed of the objective of the research, the topic covered in the interview, and its duration. During the interviews, the researcher observed and recorded aspects considered relevant for the study (both content and impressions experienced during the interaction with the participant). Finally, the interviews were transcribed.

The data obtained were submitted to content analysis. According to Bardin (2011, p. 48, our translation), content analysis is

[...] a set of techniques to analyze communications using systematic and objective procedures to describe the content of messages, seeking to obtain quantitative or qualitative indicators that allow inferring knowledge on the condition of production/reception (inferred variables) of such messages.

The data were collected, organized, categorized, and analyzed in text files and spreadsheets. The analysis of interviews, based on the dimensions of smart government obtained from the literature, was used to consolidate the results presented below and the research's conclusions.

\section{RESULTS AND DISCUSSION}

The literature review offered the following dimensions regarding the concept of smart government:

1. Use of external data and information;

2. Organizational culture based on intelligence;

3. Management efficiency and effectiveness;

4. Effective use of Technologies (big data, business intelligence);

5. Evidence based decision-making;

6. Social engagement;

7. Cross-departmental and inter-organizational collaboration;

8. Agile government;

9. Innovation, co-creation, collective intelligence.

Based on the dimensions of smart government observed in the literature, the study sought to obtain the interviewees' understanding and perception regarding the phenomenon. The interviews started with a presentation of the concept as portrayed in the literature, followed by questions seeking to identify how the interviewees observe the applicability of the concept in their current administrative practices. During the interview, the research presented the dimensions of smart government mapped in the literature review, and the participants exposed their perceptions regarding the relevance of each dimension to the development of smart government. Finally, the interviews sought to reveal the applicability of each dimension, in addition to collecting insights on the evolution of smart government based on the public managers' practice. 
The analysis of the interviews showed that only one interviewee did not know the concept and the dimensions of smart government. This phenomenon caught attention considering that government intelligence is a relatively new concept, restricted to issues of public security and foreign affairs until the mid-2000s (Cepik, 1997; Desouza, 2005; Herman, 1996) and only more recent studies show a broader orientation of the concept, applied to the public administration as a whole.

The public managers interviewed recognize the importance of structuring intelligence processes in public administration, but emphasize that these measures are still incipient, requiring further development and infrastructure. According to one interviewee:

We have plenty of data in the state. We do not have, however, information and knowledge. So, this structure needs to be designed, and we have been working in this direction with several other managers.

Participants mentioned the need for system interoperability and communication among the different state agencies to process and transform data in relevant information and knowledge to support decision-making in public management, which would characterize smart government.

For the interviewees, the concern and interest on the part of senior government management about smart government is a recent phenomenon. It has been discussed during the past two years through the creation of a smart government network, seeking to develop and systematize a process of government intelligence in the state's administration. In any case, all participants recognize the relevance of structuring processes to develop a smarter government. Among the benefits of such processes for public administration and the society as a whole, the interviewees pointed out the predictive power gained when using data and information in government; the quality and effectiveness of informed and knowledge-based management; the construction and coordination of government's databases; and delivery of effective and high-quality public services.

The benefits that public managers emphasized are in line with the benefits identified in the literature. The studies stress the importance of monitoring the environment in order to obtain data, which becomes information and knowledge supporting the government's decision-making process (Gil-Garcia et al., 2013; Gil-Garcia et al., 2016; H. J. Scholl \& M. C. Scholl, 2014). At the same time as recognizing benefits, most interviewees' pointed out that one of the challenges to implementing smart government is the need to develop and coordinate a single database providing information to the different state agencies. For one of the interviewees, the state presents an institutional weakness regarding data and information-driven operation.

In addition to the relevance and benefits of smart government observed by interviewees, the research identified which dimensions of smart government are recognized and applied (as well as their importance) for public managers. Table 1 presents a summary of the analysis, based on the response of interviewees about recognizing the dimensions and their application in public administration. The cells marked with " $\mathrm{x}$ " represent that the interviewee recognizes the dimension, and its application is highlighted in gray. The importance participants attributed to the dimensions are discussed below, also based on their responses during the interview. 


\section{TABLE 1}

\section{ANALYSIS OF DIMENSIONS ACCORDING TO PUBLIC MANAGERS}

\begin{tabular}{|c|c|c|c|c|c|c|c|c|c|c|}
\hline \multirow{3}{*}{ Dimensions of smart government } & \multicolumn{10}{|c|}{ Recognition and application of the dimensions of smart government } \\
\hline & \multicolumn{10}{|c|}{ Interviewees } \\
\hline & 1 & 2 & 3 & 4 & 5 & 6 & 7 & 8 & 9 & 10 \\
\hline Use of external data and information & $\mathrm{x}$ & $x$ & $x$ & $x$ & $x$ & $x$ & $x$ & $\mathrm{x}$ & $\mathrm{x}$ & $x$ \\
\hline Organizational culture based on intelligence & $\mathrm{x}$ & $\mathrm{x}$ & $x$ & $x$ & $x$ & $x$ & $x$ & $\mathrm{x}$ & $x$ & $x$ \\
\hline Management efficiency and effectiveness & $x$ & $x$ & $x$ & $x$ & $x$ & $x$ & $x$ & $x$ & $x$ & $x$ \\
\hline $\begin{array}{l}\text { Effective use of Technologies (big data, business } \\
\text { intelligence) }\end{array}$ & $x$ & $x$ & $x$ & $x$ & $x$ & $x$ & $x$ & $x$ & $x$ & $x$ \\
\hline Evidence based decision-making & $x$ & $x$ & $x$ & $x$ & $x$ & $x$ & $x$ & $x$ & $x$ & $x$ \\
\hline Social engagement & & & $x$ & & $x$ & & $x$ & $\mathrm{x}$ & $x$ & $x$ \\
\hline $\begin{array}{l}\text { Cross-departmental and inter-organizational } \\
\text { collaboration }\end{array}$ & $\mathrm{X}$ & $x$ & $x$ & $x$ & $x$ & $x$ & $x$ & $x$ & $x$ & $x$ \\
\hline Agile government & $x$ & $x$ & $x$ & $x$ & $x$ & $x$ & $x$ & $\mathrm{x}$ & $x$ & $x$ \\
\hline Innovation, co-creation, collective intelligence & $x$ & & $x$ & $x$ & $x$ & $x$ & $x$ & $x$ & $x$ & $x$ \\
\hline Coordination and unification of databases & $x$ & $x$ & $x$ & $x$ & $x$ & $x$ & $x$ & $x$ & $x$ & $x$ \\
\hline
\end{tabular}

Source: Elaborated by the authors.

Table 1 shows that public managers recognize most of the dimensions of smart government retrieved from the literature. Among them, the less recognized was social engagement to develop government intelligence, which may be explained by the opinion of most interviewees that the government first needs to organize and structure internal processes before establishing a connection with society as a whole. Three public managers interviewed mentioned the need to disseminate information and the dimensions of smart government throughout the public administration, so that civil servants are aware and engage in such an approach.

Against this backdrop, the question regarding the dimension of organizational culture based on intelligence is unanimously recognized by the interviewees, but none of them considers this dimension as being applied in their practice in public administration. For one of the interviewees,

[...] it is necessary to recognize that we work towards a single objective: serving society. Serving society depends on the participation and cooperation of all government agencies; they need to include in the organizational culture the importance of using data and transforming these data into information and knowledge to improve public management.

For four interviewees, the process should start with the dissemination of the concept of smart government or government intelligence, demonstrating the importance of connectivity and 
collaboration among the several governmental actors, so that decision-making is coherent and based on different views and assumptions.

According to Table 1, the use of technology through several intelligence systems and tools already developed (big data, business intelligence, and others) is well recognized and applied in public administration. For the managers interviewed, technological tools aimed at government intelligence have been implemented in the state in the last two years. They are facilitating the process of capturing data and converting them into information and knowledge necessary to improve the effectiveness of public management. However, managers emphasize the need for staff development and training in order to use such tools properly. The interviewees indicate this aspect as one of the state's current challenges.

It is worth mentioning that, during the interviews and the analyses, a new dimension emerged, different from those identified in the literature. It is listed in Table 1 as "coordination and unification of databases." According to the interviewees, this new dimension poses a significant challenge to be overcome, and it contributes to the application and development of the other dimensions of smart government. For the public managers, the lack of a coordinated and unified database serving all state agencies reduces data reliability, jeopardizing the quality of the information used in decision-making. Respondents pointed out that smart government is only possible with an organized and reliable database. They argue that the government has made little progress in unifying the databases, which restricts the capability to conduct process based on intelligence. The next section observes the results and discussion provided here, offering the final considerations of the study.

\section{FINAL CONSIDERATIONS}

This study contributes to the field by presenting an analysis of the recognition, importance, and application of the dimensions of smart government from the perspective of managers of public agencies of one of the southern states of Brazil.

A literature review was carried out to identify dimensions of smart government that are recognized and applied by public managers. Next, interviews with public managers were conducted and analyzed to confirm the dimensions identified in the literature review. The findings indicate that public managers recognize the dimensions of smart government. They also point out the importance and benefits of smartness in building more effective public administration. The main challenges for the public administration are the issues of organizational culture and the coordination and unification of the government's database. Overcoming these challenges will allow the state to implement a smarter government from the interviewees' point of view.

The fact that public managers recognize the dimensions of smart government is an essential contribution of this research, allowing future studies to advance and uncover the difficulties of developing and implementing such dimensions in government, considering that their applicability is still weak.

The need for a stronger organizational culture toward intelligence appeared prominently in the analysis of the interviews. Therefore, future research could include interviews with public servants who do not hold management positions in order to verify their understanding of smart government. 
RAP | Smart government: analysis of dimensions from the perspective of public managers

In addition, further studies on smart government should address the coordination and unification of the government's database. These efforts would allow understanding which organizational theories prove useful in the process of moving toward smart government, and a comparative study with other Brazilian states would be helpful to verify whether the problem is localized or systemic in the Brazilian context. Finally, research linking administrative practices to each of the dimensions studied are suggested to contribute to improving public management.

In conclusion, there is still a long way to go to implement small government in all its dimensions. However, the public administration already has some initiatives adopting elements suggested by the literature on the subject. This study provides subsidies for the conceptual consolidation of smart government and to improve public management, encouraging the application and development of conceptual dimensions in managerial practices. 


\section{REFERENCES}

Abrucio, F. L. (2007). Recent trajectory of the Brazilian public management: a critical assessment and the renewal of the reform agenda. Revista de Administração Pública, 41(Esp.), 67-86.

Andriotti, F. K., Freitas, H., \& Janissek-Muniz, R. (2008). Informação informal e a monitoração do ambiente organizacional: reflexões e sugestões para a área de TI. In Anais do $3^{\circ}$ Congresso Ibero Americano de Gestão do Conhecimento e Inteligência Competitiva, Brasília, DF, Brasil.

Bardin, L. (2011). Análise de conteúdo. Lisboa, Portugal: Ed. 70 .

Batista, F. F. (2012). Modelo de gestão do conhecimento para a administração pública brasileira: como implementar a gestão do conhecimento para produzir resultados em benefício do cidadão. Brasília, DF: Ipea, 2012.

Bresser-Pereira, L. C. (1996). Da administração pública burocrática à gerencial. Revista do Serviço Público, 47(1), 7-40.

Capobiango, R. P., Nascimento, A. D. L., Silva, E. A., \& Faroni, W. (2013). Reformas administrativas no Brasil: uma abordagem teórica e crítica. Revista de Gestão, 20(1), 61-78.

Cepik, M. A. (1997). Inteligência, política e poder no Estado contemporâneo. Revista de Sociologia e Política, 9, 193-196.

Cepik, M. A. (2005). Regime político e sistema de inteligência no Brasil: legitimidade e efetividade como desafios institucionais. Dados, 48(1), 67-113.

Choo, C. W. (2002). Information management for the intelligent organization: the art of scanning the environment (3 ed.). Medford, New Jersey: Information Today Inc.

Davenport, T. H. (1998). Ecologia da informação: porque só a tecnologia não basta para o sucesso na era da informação (3 ed). São Paulo, SP: Futura.

Desouza, K. C. (2005). Restructuring government intelligence programs: a few good suggestions. Government Information Quarterly, 22(3), 342-353.

Eom, S. J., Choi, N., \& Sung, W. (2016). The use of smart work in government: empirical analysis of Korean experiences. Government Information Quarterly, 33(3), 562-571.

Gil-Garcia, J. R., Helbig, N., \& Ojo, A. (2014). Being smart: emerging technologies and innovation in the public sector. Government Information Quarterly, 31, I1-I8.

Gil-Garcia, J. R., Pardo, T. A., \& Aldama-Nalda, A. (2013, June). Smart cities and smart governments: using information technologies to address urban challenges. In Proceedings of the 14th Annual International Conference on Digital Government Research (pp. 296-297), Quebec City, QC, Canada.

Gil-Garcia, J. R., Zhang, J., \& Puron-Cid, G. (2016). Conceptualizing smartness in government: an integrative and multi-dimensional view. Government Information Quarterly, 33(3), 524-534.

Guenduez, A. A., Singler, S., Tomczak, T., Schedler, K., \& Oberli, M. (2018). Smart government success factors. Yearbook of Swiss Administrative Sciences, 9(1), 96-110.

Guimarães, T. D. A., \& Medeiros, P. H. R. (2005). A relação entre governo eletrônico e governança eletrônica no governo federal brasileiro. Cadernos EBAPE.BR, 3(4), 1-18.

Herman, M. (1996). Intelligence power in peace and war. Cambridge, UK: Cambridge University Press.

Janissek-Muniz, R., Lesca, H., \& Freitas, H. (2006). Inteligência estratégica antecipativa e coletiva para tomada de decisão. Revista Organizações em Contexto, 2(4), 92-118.

Jimenez, C. E., Solanas, A., \& Falcone, F. (2014). E-government interoperability: linking open and smart government. Computer, 47(10), 22-24.

Johnston, E. W., \& Hansen, D. L. (2011). Design lessons for smart governance infrastructures. Transforming American governance: Rebooting the public square (Cap. 13, pp. 197-212). Armonk, NY: M.E. Sharpe.

Juniawan, M. A., Sandhyaduhita, P., Purwandari, B., Yudhoatmojo, S. B., \& Dewi, M. A. A. (2017). Smart government assessment using Scottish Smart City Maturity Model: a case study of Depok city. In Proceedings of the 2017 International Conference on Advanced Computer Science and Information Systems (ICACSIS), Bali, Indonésia. 
Klering, L. R., Porsse, M. C. S., \& Guadagnin, L. A. (2010). Novos caminhos da administração pública brasileira. Análise, 21(1), 4-17.

Lesca, H., \& Janissek-Muniz, R. (2015). Inteligência Estratégica Antecipativa e Coletiva: o Método LE SCAnning. Porto Alegre, RS: Pallotti.

Linders, D., Liao, C. Z. P., \& Wang, C. M. (2015). Proactive e-governance: flipping the service delivery model from pull to push in Taiwan. Government Information Quarterly, 35(4), S68-S76.

Liu, X., \& Zheng, L. (2015). Cross-departmental collaboration in one-stop service center for smart governance in China: factors, strategies and effectiveness. Government Information Quarterly, 35(4), S54-S60.

Myers, M. D. (2013). Qualitative research in business and management. London, UK: SAGE.

Nam, T. (2016). Government-driven participation and collective intelligence: a case of the Government 3.0 Initiative in Korea. Information, 7(4), 55.

Nam, T., \& Pardo, T. A. (2011). Smart city as urban innovation. In Proceedings of the 5th International Conference on Theory and Practice of Electronic Governance, New York, NY, US.

Paes de Paula, A. P. (2005). Administração pública brasileira entre o gerencialismo e a gestão social. Revista de Administração de Empresas, 45(1), 36-49.

Paula, G. D., \& Rover, A. J. (2012). O governo eletrônico e a atividade de inteligência. Revista Democracia Digital e Governo Eletrônico, 6, 216-236.

Rezende, D. A. (2018). Strategic digital city: concept and model. In Proceedings of the 15th International Conference on Information Systems \& Technology Management, São Paulo, SP, Brasil.

Ribeiro, L. M. D. P., Pereira, J. R., \& Benedicto, G. C. D. (2013). As reformas da administração pública brasileira: uma contextualização do seu cenário, dos entraves e das novas perspectivas. In Anais do $37^{\circ}$ Encontro da Associação Nacional dos Programas de
Pós-Graduação em Administração, Rio de Janeiro, RJ, Brasil.

Schaefer, E. D., Macadar, M. A., \& Luciano, E. M. (2017). Governança de tecnologia da informação interinstitucional em organizações públicas: reflexões iniciais. In Proceedings of the International Conference on Information Resources Management, Santiago de Chile, Chile.

Schoemaker, P. J., \& Day, G. S. (2009). How to make sense of weak signals. In G. R. Hickman (Ed.), Leading Organizations: Perspectives for a New Era (2 Ed., Cap. 4, pp. 37-47). Thousand Oaks, CA: Sage Publications.

Scholl, H. J., \& Scholl, M. C. (2014). Smart governance: a roadmap for research and practice. In Proceedings of the iConference 2014 (pp. 163-176), Berlin, German.

Secchi, L. (2009). Modelos organizacionais e reformas da administração pública. Revista de Administração Pública, 43(2), 347-369.

Triviños, A. N. S. (1987). Introdução à pesquisa em ciências sociais: a pesquisa qualitativa em educação. São Paulo, SP: Atlas.

Veronese, J. E. (2013). Lei de Acesso à Informação e os reflexos sobre a produção de inteligência na Polícia Federal. Revista Brasileira de Inteligência, 8, 47-57.

Viorel, B., \& Radu, I. (2015). Transformation of public management process due to competitive intelligence implementation. Procedia Economics and Finance, 32, 694-701.

Wang, L. J., Zhang, Y., Li, Q., \& Ruan, P. N. (2016). Under the background of smart city development of e-government performance evaluation: study in every districts of Beijing. In Proceedings of the 6th International Conference on Information Technology for Manufacturing Systems. Prague, Czech Republic.

$\mathrm{Xu}, \mathrm{M}$. (2007). Managing strategic intelligence: techniques and technologies. Hershey, New York: IGI Global. 


\section{Claudia Melati}

https://orcid.org/0000-0002-9369-0113

$\mathrm{PhD}$ student, master's in administration from the Graduate Program in Administration of the Federal University of Rio Grande do Sul (PPGA/UFRGS); Researcher at IEA Future Lab. E-mail: cmelati@yahoo.com.br

\section{Raquel Janissek-Muniz}

http://orcid.org/0000-0002-0657-6559

$\mathrm{PhD}$ in management from the Université de Grenoble (France); Professor and Researcher at the Graduate Program in Administration of the Federal University of Rio Grande do Sul (PPGA/UFRGS); Founder and Coordinator of the IEA Future Lab Research Group. E-mail: rjmuniz@ufrgs.br 